\title{
Proximal Femur Metastasis Treatment With Fixation or Hip Replacement. Results of 47 Patients
}

\author{
Kırk Yedi Hastada Fiksasyon veya Endoprotez ile Proksimal Femur Metastazı Tedavisi
}

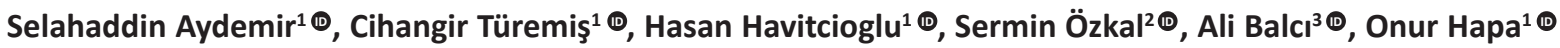 \\ ${ }^{1}$ Department of Orthopedics and Traumatology, Dokuz Eylul University Faculty of Medicine, Izmir, Turkey \\ ${ }^{2}$ Department of Pathology, Dokuz Eylul University Faculty of Medicine, Izmir, Turkey \\ ${ }^{3}$ Department of Radiology, Dokuz Eylul University Faculty of Medicine, Izmir, Turkey
}

Geliş / Received: 06.06.2021 Kabul / Accepted: 27.07.2021 Online Yayın / Published Online: 10.08.2021

Cite as: Aydemir S, Türemiş C, Havitoglu H, Özkal S, Balcı A, Hapa O. Proximal femur metastasis treatment with fixation or hip replacement. Results of 47 patients. Turk J Hip Surg 2021;1(2):61-6.

\section{ABSTRACT}

Objective: Purpose of the present study was to compare patients with proximal femur metastasis with actual or impending fractures who were treated by fixation or prosthetic hip replacement.

Method: Twenty-seven patients underwent fixation treatment (IM nail, DHS), and 20 patients prosthetic (endoprosthesis or total hip arthroplasty) replacement. Data were analyzed regarding patient demographics, cancer type, localization and type of metastasis, actual or impending fracture, number of bone metastasis, presence of spinal or visceral metastasis and treatment data (ASA class, length of hospital stay or surgery or survival, cement usage, adjuvant treatment, postoperative walking status).

Results: Fixation group (63 years) was younger than prosthesis group (70 years) ( $p$ : 0.03). Fixation was more preferred at subtrochanteric area ( $p<0.001)$. Cementation of the lesion was more preferred and surgery time was longer at fixation group ( $p: 0.01)$. Greater number of complications (mostly medical) were more likely to be seen in the fixation group (6 '1 loosening' vs 3 ' 1 dislocation').

Conclusion: It is not still clear whether one implant is clearly superior to other one, however it was revealed again that nailing was mostly preferred for the subtrochanteric area and tended to have more complications although mostly medical and unrelated to implant placement as previously reported

Keywords: proximal femur, metastasis, stabilization

öz

Amaç: Bu çalışmanın amacı, proksimal femur metastazına bağlı kalça kırığı olan veya olmak üzere olan, fiksasyon veya protezle tedavi edilen hastaları karşılaştırmaktı.

Yöntem: Fiksasyon tedavisi 27 hastada (IM çivi, DHS), 20 hastada protez (endoprotez veya total kalça protezi) tedavisi yapıldı. Veriler, hasta demografisi, kanser tipi, lokalizasyonu ve metastaz tipi, gerçek veya kırık riski, kemik metastazı sayısı, spinal veya viseral metastaz varlığı ve tedavi verileri (ASA sınıfı, hastanede kalış veya ameliyat veya sağkalım süresi, çimento kullanımı, adjuvan tedavi, postoperatif yürüme durumu) ile ilgili analiz edildi. Bulgular: Tespit grubu (63 yaş) protez grubundan (70 yaş) daha gençti ( $p: 0,03)$. Subtrokanterik alanda fiksasyon daha çok tercih edildi ( $p<0,001)$. Fiksasyon grubunda lezyonun sement uygulaması daha fazla tercih edildi ve ameliyat süresi daha uzundu (p: 0.01). Fiksasyon yapılanlarda "çoğunlukla tıbbi" daha fazla komplikasyon görülme eğilimi vardır (6'1 gevşeme" vs 3 '1 çıkık').

Sonuç: Bir implantın diğerinden açık bir şekilde üstün olduğu hala net değildir ama çivilemenin çoğunlukla subtrokanterik alan için tercih edildiği ve daha önce bildirildiği gibi çoğu tıbbi 'implantla ilgili olmamasına rağmen' daha fazla komplikasyona sahip olma eğiliminde olduğu tekrar gösterilmiştir.

Anahtar kelimeler: proksimal femur, metastaz, stabilizasyon

\section{Sorumlu Yazar / Corresponding Author:}

Selahaddin Aydemir selahaddinaydemir@gmail.com
S. Aydemir 0000-0002-4201-8239

C. Türemiş 0000-0002-5794-6652

H. Havitcioglu 0000-0001-8169-3539
S. Özkal 0000-0002-8167-0238

A. Balc1 0000-0002-5781-2910

O. Hapa 0000-0001-8154-658X

(C) Telif hakkı Türkiye Kalça Cerrahisi Dergisi'ne aittir. Logos Tıp Yayıncılık tarafindan yayınlanmaktadır. Bu dergide yayınlanan bütün makaleler Creative Commons 4.0 Uluslararası Lisansı ile lisanslanmıştır. 


\section{INTRODUCTION}

Adequate treatment of patients with proximal femur metastases demands higher level of attention due to the increasing life expectancy, and the need of maintaining good functional integrity and quality of life. In the presence of impending or actual pathologic fracture, treatment requires a reconstruction which provides pain control, stable and secure fixation and allows for immediate weight-bearing ${ }^{(1-4)}$.

Treatment of the metastatic disease of the proximal femur consists mainly of two different surgical strategies; tumor resection and reconstruction with prosthesis, or fixation with osteosynthesis, with or without local curettage or the use of bone cement. Both can be performed with different implants, including total or partial hip replacement and megaprosthesis, or intramedullary nailing (IMN) and plates, with different complication and mechanical failure rates. However, there is no evidence to support the assumption that one is obviously better than the others ${ }^{(5)}$. The best management of the metastatic disease of the proximal femur has not been clarified yet, and probably the surgeon's experience plays a critical role in the decisionmaking process for these patients ${ }^{(6)}$.

Purpose of the present study was to evaluate demographic differences, postoperative walking status, number of complications and median survival time of patients with proximal femur metastasis who were treated by fixation or prosthetic hip replacement. Hypothesis was that IMN of the metastatic lesion would result at lower morbidity and mortality with better walking status compared to prosthesis treatment.

\section{PATIENTS AND METHODS}

Forty seven patients were analyzed retrospectively. All had actual or impending fracture of the proximal femur. The research was performed in accordance with declaration of Helsinki, and local ethics committee approval was obtained.

Twenty-seven patients underwent internal fixation treatment using proximal femoral nail in 26, and dynamic hip screw (DHS) in one patient. Twenty patients were treated with prosthetic replacement (total hip replacement, $\mathrm{n}: 8$; cemented, $\mathrm{n}: 1$; uncemented, $n: 5$; long stem, $n: 2$; resection, $n: 1$ and 12; endoprosthesis, $n: 12$ (cemented, $n: 6$; uncemented, $\mathrm{n}: 5$, and long stem, $\mathrm{n}: 1$ ) (Figures 1 and 2).

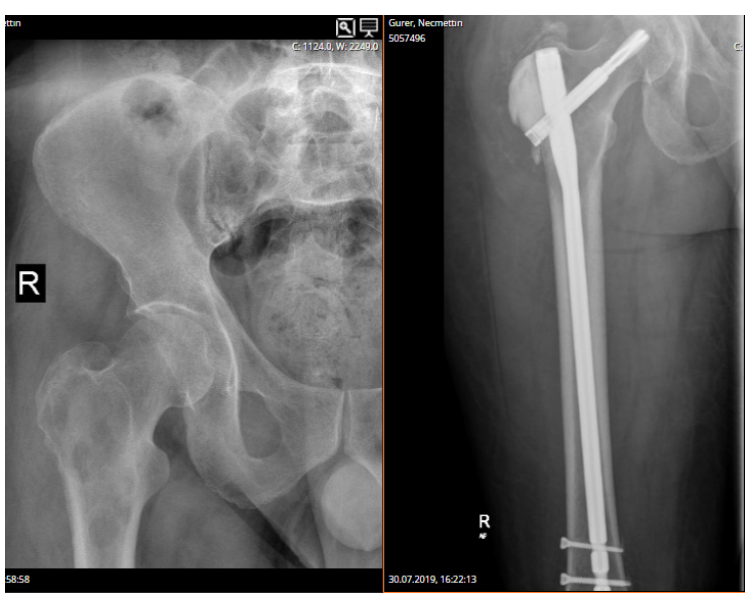

Figure 1. IM nailing+ cementation of lytic lesion at trochanteric area

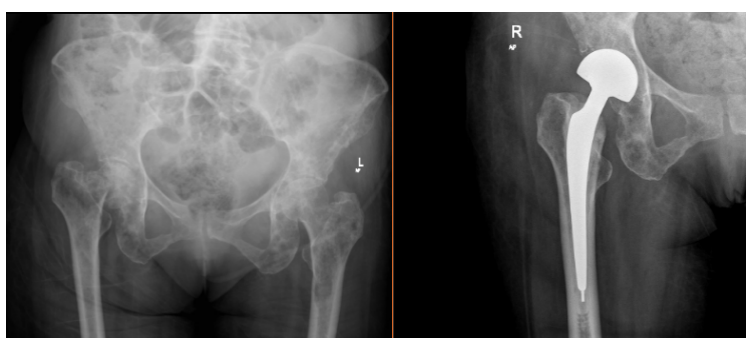

Figure 2. Pathologic femur neck fracture treated with endoprosthesis.

Data were analyzed regarding patient age, sex, cancer type, localization (femoral neck, intertrochanteric, subtrochanteric) and type of metastasis, actual or impending fracture, number of bone metastasis, presence of spinal or visceral metastasis and treatment data (ASA class, length of hospital stay, surgery or survival, cement usage, adjuvant treatment, postoperative walking status).

\section{Statistical analysis}

Data analysis was performed using SPSS for Windows, version 22 (IBM, SPSS statistics). A value of $p<0.05$ was considered as statistically significant. Chi-square and Mann-Whitney $U$ tests were used to compare variables in both groups.

\section{RESULTS}

Patient demographics are given in Tables I and II. 
Table I Patient demographics

\begin{tabular}{|c|c|c|}
\hline Type of surgery & Fixation (n:27) & Prosthesis (n:20) \\
\hline Age $($ mean \pm SD) & $63 \pm 13$ & $70 \pm 10$ \\
\hline Female/male & $9 / 18$ & $10 / 10$ \\
\hline $\begin{array}{l}\text { Type of cancer } \\
\text { Breast } \\
\text { Lung } \\
\text { Lymphoma } \\
\text { Kidney/bladder } \\
\text { Prostate } \\
\text { Liver/Biliary } \\
\text { Thyroid } \\
\text { Colon }\end{array}$ & $\begin{array}{l}3 \\
10 \\
2 \\
2 \\
4 \\
1 \\
1 \\
1\end{array}$ & $\begin{array}{l}6 \\
4 \\
1 \\
1 \\
3 \\
2 \\
1 \\
1\end{array}$ \\
\hline $\begin{array}{l}\text { Location } \\
\text { Femur neck } \\
\text { Intertrochanteric } \\
\text { Subtrochanteric }\end{array}$ & $\begin{array}{l}1 \\
7 \\
19\end{array}$ & $\begin{array}{l}8 \\
9 \\
3\end{array}$ \\
\hline $\begin{array}{l}\text { Type } \\
\text { Lytic } \\
\text { Blastic } \\
\text { Mixed }\end{array}$ & $\begin{array}{l}18 \\
7 \\
2\end{array}$ & $\begin{array}{l}12 \\
7 \\
1\end{array}$ \\
\hline $\begin{array}{l}\text { Pathologic fracture } \\
\text { Actual } \\
\text { Impending }\end{array}$ & $\begin{array}{l}14 \\
13\end{array}$ & $\begin{array}{l}15 \\
5\end{array}$ \\
\hline $\begin{array}{l}\text { Number of bone metastases } \\
\quad \begin{array}{l}1 \\
\leq 3 \\
>3\end{array}\end{array}$ & $\begin{array}{l}8 \\
9 \\
10\end{array}$ & $\begin{array}{l}7 \\
5 \\
8\end{array}$ \\
\hline Visceral metastases & 14 & 10 \\
\hline Spinal metastases & 4 & 5 \\
\hline
\end{tabular}

\section{Table II Treatment details and results}

\begin{tabular}{|c|c|c|}
\hline Surgery & Fixation (n:27) & Prosthesis $(\mathrm{n}: 20)$ \\
\hline $\begin{array}{c}\text { ASA class } \\
2 \\
3 \\
4\end{array}$ & $\begin{array}{l}5 \\
19 \\
3\end{array}$ & $\begin{array}{l}3 \\
12 \\
5\end{array}$ \\
\hline Cementation & 20 & 5 \\
\hline Operative time $_{\text {min }}$ & 161 & 134 \\
\hline Hospital length $_{\text {day }}$ & 15 & 13 \\
\hline $\begin{array}{l}\text { Adjuvant treatments } \\
\text { Radiation therapy } \\
\text { Chemotherapy } \\
\text { Chemo+radiation therapy } \\
\text { None }\end{array}$ & $\begin{array}{l}3 \\
4 \\
18 \\
2\end{array}$ & $\begin{array}{l}3 \\
2 \\
11 \\
4\end{array}$ \\
\hline $\begin{array}{l}\text { Postoperative walking status } \\
\text { Normal } \\
\text { With the aid of } \\
1 \text { crutch } \\
2 \text { crutches/frame } \\
\text { Impossible }\end{array}$ & $\begin{array}{l}8 \\
9 \\
7 \\
3\end{array}$ & $\begin{array}{l}10 \\
2 \\
5 \\
3\end{array}$ \\
\hline Complication & 6 & 3 \\
\hline Survival $_{\text {months }}$ & 16 & 18 \\
\hline
\end{tabular}


Fixation group (63 years) was younger than prosthesis group (70 years) ( $p: 0.03)$. Other demographics were not different between groups $(p>0.05)$.

Fixation was more frequently preferred at subtrochanteric area $(p<0.001)$. Cementation of the lesion was more often preferred and surgery time was longer in the fixation group ( $p: 0.01$ ). However length of hospital stay, postoperative walking score or length of survival did not differ between groups $(p>0.05)$. Although not statistically significant $(p>0.05)$, greater number of complications were seen in the fixation group ( $n: 6$; loosening, $n: 1$; infections, $n: 4$, and peri-implant fracture, $n: 1)$ than the prosthesis group ( $\mathrm{n}: 3$; infection, $\mathrm{n}: 1$; pulmonary embolus, $\mathrm{n}: 1$, and dislocation, $\mathrm{n}: 1$ ).

\section{DISCUSSION}

Main findings of the present study revealed that postoperative functional status and length of survival did not differ between groups. However there were some minor differences between groups in that, fixation group was younger (63 vs 70), fixation was preferred commonly at subtrochanteric area with longer operative time (161 min vs $134 \mathrm{~min}$ ) and lesion was more often cemented compared to prosthesis group. Finally, fixation group tended to have greater number of complications than the prosthesis group.

There are still controversies in the literature regarding the choice of best implant for this group of patients. Tsai et al ${ }^{(7)}$. reported that prosthesis replacement was related to better implant survival especially when there is better postoperative ambulatory status while for patients with poor ambulatory status, mechanical failures did not differ so they offered fixation for the patient with anticipated poor postoperative ambulatory performance. In the present study both postoperative walking status and number of implant- related problems have not differed between groups.

In another study, Gao et $\mathrm{al}^{(8)}$, reported that while surgical traumas including surgical, and hemorrhagic complications were more frequently seen in the endoprothesis group compared to intramedullary nailing, similar to the present study, they preferred endoprosthesis for metastasis above trochanteric area, but unlike our study they also opted to use this method for younger patients due to better functional outcomes with prosthesis with a median survival of 11 months in both groups.

In another recent study, one year survival was $\% 58$ similar to the literature with higher survival rates reported for patients having renal cancer metastasis or myeloma relative to breast, lung cancer and treated with proximal femur resection compared to endoprosthetic replacement or IM nailing. Most frequent complication was dislocation followed by wound infection ${ }^{(4)}$.

Supporting this, a recent review reported that prosthetic dislocation is the most common complication observed in cases with prosthetic replacement of proximal femur ${ }^{(6)}$ while loosening being the main cause of re-operation in the fixation group, usually occuring from 6 months to two years after surgery due to the non-healing of the pathological fracture ${ }^{(9-11)}$ so they most advocated internal fixation of the pathological fracture for patients with poor life expectancy (generally less than six months) due to lower medical complication rate compared to prosthetic replacement (6,9-11). Another extensive report revealed that the only factor affecting the stability of IM nail was length of patient survival beyond 7 months while histology of the tumour did not have any effect. They again had biases selecting IM nail over prosthesis where head or neck was not affected and size of lesion was not $\operatorname{larg} \mathrm{e}^{(12)}$.

In the present study mostly medical complications were seen in both groups while only two patients had mechanical problems (one loosening in the fixation group, and one dislocation of the prothesis).

In another study, Yu et al ${ }^{(13)}$. reported higher functional score for endoprosthesis group compared to IM nailing group at postoperative 6 months while longer survival, operative, and hospitalization times (10mo vs $7.5 \mathrm{mo}, 142 \mathrm{~min}$ vs $98 \mathrm{~min}, 8$ days vs 5 days), but lower complication rates (10\% vs $29 \%$ ) were observed in the prosthesis group. Mostly medical complications were seen like thrombosis, infection with only one implant- related dislocation, 
while in the IMN group most complications were nail breakage or nonunion related to placement of implants ${ }^{(13)}$.

Partly contradicting these results, Meynard et al (14), reported similar rates of functional recovery, walking capacity, survival for hip replacement versus nailing. Rates of again mostly medical complications still did not differ between two groups They related this finding to the fact that while prosthesis is indicated in cervical or cephalic lesions, both can be used in subtrochanteric locations. However they admitted that although prosthesis surgery is a more challenging procedure, it reduces tumor mass and allows immediate weight bearing. Main question is which implant is the best to be used for metaphyseal lesions.

Guzik $G$ et al. (15) reported that optimum results would be obtained in patients without actual fracture where tumor resection with wide healthy margin and implantation of a prosthesis could be applied. They did not describe any implant -related complications like dislocation or loosening other than frequent medical complications. Recent study has also reported that wide resection with endoprosthetic replacement provided durable fixation with a higher implant survival rate (1-year survival rate of $\% 72)^{(16)}$.

Finally, a survey among members of Bone and Soft Tissue Tumor Study Group of Japan concluded that prosthesis is clearly preferred if the lesion involves head, neck or calcar area, has soft tissue extension or transverse destruction of more than half of the bone ${ }^{(17)}$.

Present study do have limitations. Firstly, data were collected retrospectively, this case series were not performed by a single surgeon and two groups were not homogeneous in that fixation was preferred for younger patients with subtrochanteric localization. Choice of implant somewhat depended on surgeon's experience. However in line with the literature, the present study has not clarified the superiority of one implant over others. In the present study, nailing was mostly preferred for the subtrochanteric area and it tended to cause more often, mostly medical, complications unrelated to implants as previously reported. Extent of excision and type of prosthesis used changed greatly among studies.

In conclusion, although fixation group was younger (63 vs 70) and fixation was preferred commonly at fractures of the subtrochanteric area, operative time was longer (161 min vs $134 \mathrm{~min}$ ), the lesion was more often cemented and fixation tended to be more frequently associated with complications compared to prosthesis group, postoperative functional status and survival time did not differ between two groups.

Ethics Committee Approval: The study was approved by Local Ethic Committee in Dokuz Eylul University (2016/31-29).

Conflict of Interest: None.

Funding: None.

Informed Consent: Not necessery

\section{REFERENCES}

1. Swanson KC, Pritchard DJ, Sim FH. Surgical treatment of metastatic disease of the femur. J Am Acad Orthop Surg 2000;8(1):56

https://doi.org/10.5435/00124635-200001000-00006

2. Papagelopoulos PJ, Savvidou OD, Galanis EC, Mavrogenis AF, Jacofsky DJ, Frassica FJ, et al. Advances and challenges in diagnosis and management of skeletal metastases. Orthopedics 2006;29(7):609.

https://doi.org/10.3928/01477447-20060701-01

3. Lane JM, Sculco TP, Zolan S. Treatment of pathological fractures of the hip by endoprosthetic replacement. J Bone Joint Surg Am 1980;62:954-9.

https://doi.org/10.2106/00004623-198062060-00011

4. Angelini A, Trovarelli G, Berizzi A, Pala E, Breda A, Maraldi M, Ruggieri P.Treatment of pathologic fractures of the proximal femur. Injury. 2018 Nov;49 Suppl 3:S77-S83. https://doi.org/10.1016/j.injury.2018.09.044

5. Issack PS, Barker J, Baker M, Kotwal SY, Lane JM. Surgical management of metastatic disease of the proximal part of the femur. J Bone Joint Surg Am 2014;96:2091-8. https://doi.org/10.2106/JBJS.N.00083

6. Di Martino A, Martinelli N, Loppini M, Piccioli A, Denaro V. Is endoprosthesis safer than internal fixation for metastatic disease of the proximal femur? A systematic review. Injury. 2017 Oct;48 Suppl 3:S48-S54. 7 https://doi.org/10.1016/S0020-1383(17)30658-7

7. Tsai SW, Wu PK, Chen CF, Chang MC, Chen WM. Postoperative Ambulatory Performance Status Significantly Affects Implant Failure Rate Among Surgical Treatment Strategies in Patients With Proximal Femur Metastasis. Artif Organs. 2017 Jun;41(6):585-592. https://doi.org/10.1111/aor.12795

8. 7.Gao H, Liu Z, Wang B, Guo A. Clinical and functional comparison of endoprosthetic replacement with intramedullary nailing for treating proximal femur metastasis. Chin J Cancer Res. 2016 Apr;28(2):209-14. https://doi.org/10.21147/j.issn.1000-9604.2016.02.08 
9. Wedin R, Bauer HC. Surgical treatment of skeletal metastatic lesions of the proximal femur: endoprosthesis or reconstruction nail? J Bone Joint Surg Br 2005;87:1653-7. https://doi.org/10.1302/0301-620X.87B12.16629

10. Weiss RJ, Ekström W, Hansen BH, Keller J, Laitinen M, Trovik C, et al. Pathological subtrochanteric fractures in 194 patients: a comparison of outcome after surgical treatment of pathological and non-pathological fractures. J Surg Oncol 2013;107:498-504 https://doi.org/10.1002/jso.23277

11. Arvinius C, Parra JL, Mateo LS, Maroto RG, Borrego AF, Stern LL. Benefits of early intramedullary nailing in femoral metastases. Int Orthop 2014;38:129-32. https://doi.org/10.1007/s00264-013-2108-x

12. Chafey DH, Lewis VO, Satcher RL, Moon BS, Lin PP. Is a cephalomedullary nail durable treatment for patients with metastatic peritrochanteric disease? Clin Orthop Relat Res. 2018 Dec;476(12):2392-2401. https://doi.org/10.1097/CORR.0000000000000523

13. Yu Z, Xiong Y, Shi R, Min L, Zhang W, Liu H, Fang X, Tu C, Duan H.Surgical management of metastatic lesions of the proximal femur with pathological fractures using intramedullary nailing or endoprosthetic replacement. Mol Clin Oncol. 2018 Jan;8(1):107-114.

https://doi.org/10.3892/mco.2017.1503
14. Meynard $P$, Seguineau $A$, Laumonerie $P$, Fabre $T$, Foltran $D$, Niglis L, Descamps J, Bouthors C, Lebaron M, Szymanski C, Sailhan F, Bonnevialle P; members of the SoFCOT. Surgical management of proximal femoral metastasis: Fixation or hip replacement? A 309 case series. Orthop Traumatol Surg Res. 2020 Oct;106(6):1013-1023. https://doi.org/10.1016/j.otsr.2020.05.007

15. Guzik G. Oncological and functional results after surgical treatment of bone metastases at the proximal femur. BMC Surg. 2018 Jan 25;18(1):5. https://doi.org/10.1186/s12893-018-0336-0

16. Sofulu O, Sirin E, Saglam F, Tokyay A, Igrek S, Erol B. Implant survival and functional results of endoprosthetic reconstruction for proximal femoral metastases with pathological fractures. Hip Int. 2021 May 2:11207000211014813.

17. Araki N, Chuman H, Matsunobu T et al. Factors associated with the decision of operative procedure for proximal femoral bone metastasis: Questionnaire survey to institutions participating the Bone and Soft Tissue Tumor Study Group of the Japan Clinical Oncology Group. J Orthop Sci. 2017 Sep;22(5):938-945.

https://doi.org/10.1016/j.jos.2017.05.012 